\title{
Perbandingan Kekuatan Kolom Berdasarkan SNI 2847:2013 dan SNI 2847:2019
}

\author{
Ahmad Hernadi*1, Rini Sahara², Septa Utami Dewi ${ }^{3}$ \\ ${ }^{1,2,3}$ Universitas Borneo Tarakan, Jl. Amal Lama No. 1, Tarakan \\ e-mail: *1ahernjineering@gmail.com
}

\begin{abstract}
Today, Practitioners of Civil Engineering in Indonesia are still using SNI 2847:2013 as code for reinforcement concrete design. As we know that SNI 2847:2019 been published, but practitioners still not yet use it.The point of design and evaluation in SNI 2847 code is reduction factor $(\phi)$ that could influence strength design of structure base on it behaviour. Load in Column is not just axial load, but flexural and combine of axial and flexural. This behavior makes the column has variate reduction factor and it can shown by interaction diagram. This research is compare between SNI 2847:2013 and SNI 2847:2019 for column with section 400x500, $f c^{\prime} 20 \mathrm{MPa}$ and reinforcement ratio 1\%. Result of this research is compare between SNI 2847:2013 and SNI 2847:2019 for column with variation fy is not too significant. So when the column of SNI 2847:2013 inspected or evaluated by SNI 2847:2019 is not distinction.
\end{abstract}

Keywords: Column, Interaction Diagaram, SNI 2847:2013, SNI 2847:2019

\begin{abstract}
Abstrak
Saat ini masih banyak praktisi yang menggunakan SNI 2847:2013 dalam mendisain elemen struktur beton bertulang dikarenakan SNI 2847:2019 baru saja diterbitkan. Salah satu unsur penting dalam perencanaan pada SNI 2847 adalah penggunaan faktor reduksi $(\phi)$ yang akan mempengaruhi kekuatan rencana tergantung pada perilaku strukturnya. Perilaku kolom yang tidak hanya menerima beban aksial saja melainkan gabungan lentur atau lentur saja, sehingga faktor reduksi yang digunakan juga cukup variatif. Hal ini dapat digambarkan dengan diagaram interkasi kolom. Dengan membandingkan kekuatan kolom yang menggunakan SNI 2847:2013 dan SNI 2847:2019 dengan variasi mutu baja tulangan $f_{y}$ 390, 400 dan $420 \mathrm{MPa}$, maka dapat disimpulkan perbedaan antara kedua SNI pada kolom dengan penampang $400 \times 500$ dengan $f_{c}^{\prime} 20$ MPa serta rasio tulangan $1 \%$ tidak terdapat perbedaan yang signifikan, atau dapat dikatakan sama. Sehingga perencanaan kolom yang masih menggunakna SNI 2847:2013 masih dapat diakomodir bila dievaluasi menggunakan SNI 2847:2019
\end{abstract}

Kata kunci: Diagram Interksi, Kolom, SNI 2847:2013, SNI 2847:2019

\section{Pendahuluan}

Pada akhir tahun 2019, Badan Standarisasi Nasional (BSN) telah menetapkan standar/ acuan yang erat kaitannya dengan bidang teknik sipil sebagaimana yang tercantum dalam surat nomor: 
4357/BSN/B2-b2/12/2019 tentang Penyampaian Keputusan Kepala Badan Standarisasi Nasional. Adapun isi dari surat keputusan tersebut adalah:

1. Keputusan Kepala Badan Standarisasi Nasional Nomor 667/KEP/BSN/12/2019 tentang Penetapan Standar Nasioanal Indonesia International Organization for Standarzation/Technical Report 24578:2012 Hidrometri-Acoustic Doppler Profiler Metode dan penerapan pengukuran aliran pada saluran terbuka;

2. Keputusan Kepala Badan Standarisasi Nasional Nomor 693/KEP/BSN/12/2019 tentang Penetapan Standar Nasioanal Indonesia 1726:2019 Tata cara perencanaan ketahanan gempa untuk struktur bangunan gedung dan nongedung sebagai revisi dari Standar Nasional Indonesia 1726:2012 Tata cara perencanaan ketahanan gempa untuk struktur bangunan gedung dan nongedung; dan

3. Keputusan Kepala Badan Standarisasi Nasional Nomor 694/KEP/BSN/12/2019 tentang Penetapan Standar Nasioanal Indonesia 2847:2019 Persyaratan beton struktural untuk bangunan gedung dan penjelasan sebagai revisi dari Standar Nasional Indonesia 2847:2013 Persyaratan beton struktural untuk bangunan gedung.

Dengan diterbitkannya surat keputusan BSN tentang penetapan SNI 2847:2019 maka akan berpengaruh terhadap perencanaan yang masih menggunakan SNI 2847:2013 atau bahkan SNI 2847:2002. Pada Surat Keputusan Kepala Badan Standarisasi Nasional Nomor 694/KEP/BSN/12/2019 tersebut, ada klusal yang berbunyi SNI yang direvisi masih tetap berlaku sepanjang belum dicabut dan dinyatakan tidak berlaku. Hingga saat ini SNI yang direvisi tersebut belum dicabut, sehingga saat ini kita masih bisa menggunakan 2 SNI yang "berbeda" dalam hal perencanaan atau evaluasi pada struktur beton. Selain perbedaan tata cara penulisan, perbedaan yang cukup jelas terdapat pada faktor reduksi kekuatan $(\phi)$ antara SNI 2847:2013 (selanjutnya akan ditulis SNI 2013 saja) dan SNI 2847:2019 (selanjutnya akan ditulis SNI 2019 saja) terutama pada daerah transisi.

Faktor reduksi kekuatan $(\phi)$ merupakan salah satu variabel yang sangat penting dalam menentukan kekuatan rencana dari suatu elemen struktural, terutama pada elemen struktur kolom beton bertulang. SNI 2019 merupakan terjemahan dari ACI 318-14 sedangkan SNI 2013 merupakan adopsi dari ACI 318-11, sehingga banyak penelitian yang membandingkan antara SNI lama dengan SNI terbaru maupun SNI terbaru dengan ACI terbaru. Penelitian-penelitian sejenis yang pernah dilakukan dengan membandingkan antara SNI 2848:2002, SNI 2013, ACI 318-02 dan ACI 318-11 pada elemen struktur kolom memberikan hasil penggunaan standar terbaru memiliki kekuatan nominal yang lebih besar dari standar sebelumnya, terutama dari kekuatan momen (Arfiadi, 2016; Piscesa, 2006; Sartika, Gunawan, \& Hisyam, 2017)

Cara mudah untuk menentukan kekuatan nominal dan kekuatan rencana dari suatu kolom adalah dengan menggambarkan hubungan antara gaya aksial (P) dan momen (M) dalam sebuah kurva yang disebut diagram interaksi. Kolom dikatakan kuat menahan beban aksial, momen ataupun kombinasi keduanya apabila beban yang terjadi berada di dalam diagram ini. Diagram interaksi kolom dibuat sesuai dengan kebutuhan, terutama untuk melakukan pengecekan pada profil dengan konfigurasi tulangan yang telah ditentukan terbukti secara cepat dapat mengevaluasi apakah kombinasi gaya aksial-momen pada dua arah masih aman (Subrinato, Puryanto, \& Firdausa, 2020)

Atas dasar itulah penelitian ini mencoba meneliti "sejauh" apa perbedaan kekuatan nominal dari suatu kolom beton berulang dengan perbedaan faktor reduksi kekuatan $(\varnothing)$ antara SNI 2013 dan SNI 2019. Adapun studi kasus yang diangkat adalah diagram interaksi kekuatan nominal kolom beton bertulang ukuran 400x500 dengan variasi mutu tulangan (fy) $390 \mathrm{MPa}, 400 \mathrm{MPa}$, dan $420 \mathrm{MPa}$. 


\section{Metode Penelitian}

Metode penelitian pada tulisan ini adalah komparasi kekuatan ultimit dari suatu penampang kolom beton bertulang bila menggunakan SNI 2013 dan SNI 2019 dengan menggunakan diagram interaksi. Perbandingan kekuatan penampang kolom ini ditinjau dengan variasi mutu baja tuangan yaitu $\mathrm{f}_{\mathrm{y}} 390$ $\mathrm{MPa}, \mathrm{f}_{\mathrm{y}} 400 \mathrm{MPa}$ dan $\mathrm{f}_{\mathrm{y}} 420 \mathrm{MPa}$.

\subsection{Kolom}

Kolom merupakan salah satu elemen vertikal dari suatu struktur yang dibebani beban aksial dengan atau tanpa momen untuk diteruskan ke pondasi, baik beban aksial akibat berat sendiri maupun beban aksial akibat beban luar. Kekuatan rencana dari suatu kolom adalah berbanding lurus antara faktor reduksi kekuatan dan kekuatan nominalnya. Oleh karena itu, kolom harus dirancang mampu menahan beban terfaktor pada semua lantai atau atap dan momen maksimum dari beban terfaktor pada suatu bentang lantai atap bersebalahan yang ditinjau (Badan Standarisasi Nasional, 2013). Hal ini juga dijelaskan dalam SNI 2019 Pasal 10.5, yang dapat dituliskan dengan persamaan 1 dan 2,

$$
\begin{gathered}
\phi \mathrm{P}_{\mathrm{n}} \leq \mathrm{P}_{\mathrm{u}} \\
\phi M_{n} \leq M_{u}
\end{gathered}
$$

dimana:,

$$
\begin{array}{ll}
\phi P_{n} & =\text { beban aksial rencana } \\
P_{u} & =\text { beban aksial yang terjadi (ultimit) } \\
\phi M_{n} & =\text { momen rencana } \\
M_{u} & =\text { momen yang terjadi (ultimit) }
\end{array}
$$

\begin{tabular}{|c|c|c|c|}
\hline & Gaya atau elemen struktur & $\phi$ & Pengecualian \\
\hline $\mathrm{a}$ & $\begin{array}{l}\text { Momen, gaya aksial, atau kombinasi momen } \\
\text { dan gaya aksial }\end{array}$ & $0,65-0,9$ & $\begin{array}{l}\text { Di dekat ujung komponen pratarik } \\
\text { (pretension) dimana strand belum } \\
\text { sepenuhnya bekerja }\end{array}$ \\
\hline $\mathrm{b}$ & Geser & 0,75 & $\begin{array}{l}\text { Persyaratan khusus untuk struktur } \\
\text { tahan gempa terdapat pada } 21.2 .4 \\
\text { SNI } 2019\end{array}$ \\
\hline $\mathrm{c}$ & Torsi & 0,75 & - \\
\hline d & Tumpu (bearing) & 0,65 & - \\
\hline $\mathrm{e}$ & Zona angkurpascatarik (post-tension) & 0,85 & - \\
\hline f & Bracket dan korbel & 0,75 & - \\
\hline $\mathrm{g}$ & $\begin{array}{l}\text { Strut, ties, zona nodal, dan daerah tumpuan } \\
\text { yang dirancang dengan strut-and-tie di Pasal } \\
23 \text { SNI } 2019\end{array}$ & 0,75 & - \\
\hline $\mathrm{h}$ & $\begin{array}{l}\text { Komponen sambungan beton pracetak } \\
\text { terkontrol leleh oleh elemen vaja dalam tarik }\end{array}$ & 0,9 & - \\
\hline
\end{tabular}

Dimana nilai $\phi$ harus sesuai dengan Pasal 22.2 dalam SNI 2019 yang ditunjukkan pada Tabel 1,

Tabel 1 Nilai faktor reduksi kekuatan $(\phi)$ secara umum 
Tabel 2 Komparasi nilai faktor reduksi kekuatan ( $\phi)$ SNI 2013 dan SNI 2019 dengan tulangan transversal lainnya

\begin{tabular}{cccc}
\hline $\begin{array}{c}\text { Regangan Tarik } \\
\text { netto }\left(\varepsilon_{\mathrm{t}}\right)\end{array}$ & Klasifikasi & \multicolumn{2}{c}{$\begin{array}{c}\boldsymbol{\phi} \\
\text { (Tulangan non spiral) }\end{array}$} \\
\cline { 3 - 4 }$\varepsilon_{\mathrm{t}}<\varepsilon_{\mathrm{ty}}$ & $\begin{array}{c}\text { Terkontrol } \\
\text { tekan }\end{array}$ & 0,65 & SNI 2019 \\
$\varepsilon_{\mathrm{ty}}<\varepsilon_{\mathrm{t}}<0,005$ & Transisi & $0,65+\left(\varepsilon_{t}-0,002\right)(250 / 3)$ & 0,65 \\
$\varepsilon_{\mathrm{t}} \geq 0,005$ & Terkontrol tarik & 0,9 & $0,65+0,25 \frac{\left(\varepsilon_{\mathrm{t}}-\varepsilon_{\mathrm{ty}}\right)}{\left(0,005-\varepsilon_{\mathrm{ty}}\right)}$ \\
\hline
\end{tabular}

\subsection{Batasan Luas Tulangan Longitudinal}

Luas tulangan utama atau tulangan longitudinal dari suatu kolom sekurang-kurangnya sebesar 0,01 $\mathrm{A}_{\mathrm{g}}$ dan tidak lebih dari $0,08 \mathrm{~A}_{\mathrm{g}}$; dimana $\mathrm{A}_{\mathrm{g}}$ adalah luas luas penampang dari kolom (Badan Standarisasi Nasional, 2013, 2019)(Badan Standarisasi Nasional, 2013, 2019). Batas bawah 0,01 $\mathrm{Ag}_{\mathrm{g}}$ bertujuan untuk mengendalikan deformasi plastis dan unuk mendapatkan momen lebih besar dari momen retak (Purwonno \& Aji, 2014)

\subsection{Kekuatan Kolom Akibat Beban Aksial}

Seperti telah dikemukakan sebelumnya bahwa kolom merupakan elemen struktur yang menerima beban aksial baik dengan atau tanpa momen, sehingga fungsi utama dari kolom adalah menahan beban aksial. Beban aksial adalah beban yang arah kerjanya searah atau berlawanan arah dengan panjang dari suatu elemen. Pada kolom, arah beban searah gaya gravitasi merupakan beban aksial tekan sedangkan ketika berlawanan arah gravitasi merupakan beban aksial tarik. Beban aksial ini dapat membebani kolom tepat di pusat berat plastisnya (kondisi sentris) maupun tidak (kondisi eksentris). Kekuatan nominal dari suatu kolom dengan aksial tekan sentris dituliskan pada persamaa 3 berikut ini,

$$
P_{o}=0,85 f_{c}^{\prime}\left(A_{g}-A_{s t}\right)+f_{y} A_{s t}
$$

Dalam praktiknya, keadaan beban aksial sentris dari suatu kolom sangat jarang terjadi bahkan dianggap tidak ada (Asroni, 2010). Oleh karena itu, SNI 2013 dan SNI 2019 membatasi kekuatan kolom dengan beban sentris ini sebesar $80 \%$ untuk kolom dengan sengkang pengikat dan $85 \%$ untuk sengkang spiral, sehingga kekuatan nominal maksimal untuk beban aksial tekan sentris menjadi,

$$
P_{n, \max }=0,80 P_{o}=0,80\left[0,85 f^{\prime}{ }_{c}\left(A_{g}-A_{s t}\right)+f_{y} A_{s t}\right]
$$

(untuk tulangan sengkang pengikat)

$$
P_{n, \max }=0,85 P_{o}=0,85\left[0,85 f^{\prime}{ }_{c}\left(A_{g}-A_{s t}\right)+f_{y} A_{s t}\right]
$$

(untuk tulangan sengkang spiral)

Selain menerima beban aksial tekan, kolom juga dapat menerima beban aksial tarik yang kekuatan nominalnya adalah:

$$
\begin{aligned}
& \mathrm{P}_{\mathrm{nt}}=-\mathrm{f}_{\mathrm{y}} \mathrm{A}_{\mathrm{st}} \\
& A_{s t}=A_{s}+A^{\prime}{ }_{s}
\end{aligned}
$$

Dimana:

$$
P_{o} \quad=\text { kekuatan aksial tekan dalam kondisi sentris }
$$




$$
\begin{array}{ll}
P_{n, \max } & =\text { kekuatan aksial tekan maksimal nominal } \\
P_{n t} & =\text { kekuatan aksial tarik nominal } \\
A_{g} & =\text { luas penampang kolom } \\
A_{s t} & =\text { luas total tulangan longitudinal } \\
f_{c} & =\text { mutu kuat tekan beton } \\
f_{y} & \quad=\text { mutu baja tulangan }
\end{array}
$$

\subsection{Kekuatan Kolom Akibat Beban Aksial dan Lentur}

Kekuatan kolom yang menerima beban aksial dan lentur secara bersamaan ditimbulkan akibat ketidaktepatan beban pada pusat berat plastis. Besarnya momen ini tergantung dari jarak beban ke titik berat plastis yang disebut eksentrisitas (e).

$$
\mathrm{M}=\mathrm{Pe}
$$

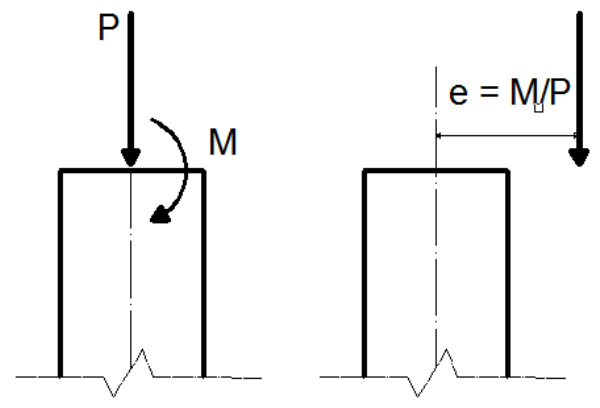

\section{Gambar 1 Kolom dengan beban aksial dan momen lentur}

Kondisi beban aksial dan lentur inilah yang paling mungkin terjadi pada suatu konstruksi kolom. Bila e tidak terlalu besar, maka ketika kolom menerima beban aksial yang melebihi kapasitas rencana, beton pada kolom akan mengalami keruntuhan yang diebut keruntuhan tekan. Sebaliknya, bila e sangat besar, maka kolom akan mengalami keruntuhan tarik. Namun ada batasan kapan nilai e sangat besar dan sangat kecil. Nilai batasan itu adalah eb atau eksentrisitas dalam keadaan seimbang, dimana dalam keadaan seimbang ini terjadi keruntuhan antara beton dan tulangan secara bersamasama.

\subsection{Keruntuhan Kolom}

Berdasarkan peneltian dan pengamatan, regangan tekan maksimum $\left(\varepsilon_{\mathrm{cu}}\right)$ saat beton mengalami keruntuhan/kehancuran bervariasi antara 0,003 hingga lebih dari 0,008 dalam kondisi tertentu. Namun pada umumnya, nilai regangan maksimum tekan yang terjadi pada komponen beton dangan proporsi material dan kekuatan normal berkisar antara 0,003 sampai 0,004 saat mencapai kekuatan nominalnya. Regangan tekan maksimum untuk serat tekan terjauh pada beton diasumsikan sama dengan 0,003 dan kekuatan tarik beton dapat diabaikan. Baja tulangan akan mengalami keruntuhan/leleh ketika regangannya sebesar $\varepsilon t y$. Untuk tulangan ulir dengan mutu baja tulangan $\left(\mathrm{f}_{\mathrm{y}}\right)$ 
$420 \mathrm{MPa} \varepsilon_{\mathrm{ty}}$ diizinkan diambil sebesar 0,002 (SNI 2847:2013, 2013 dan SNI 2847:2019, 2019). $\varepsilon_{\mathrm{ty}}$ ini dapat dihitung dengan persamaan:

$$
\varepsilon_{\mathrm{ty}}=\frac{\mathrm{f}_{\mathrm{y}}}{\mathrm{E}_{\mathrm{s}}}
$$

dimana nilai elastisitas baja tulangan $\left(\mathrm{E}_{\mathrm{s}}\right)=200.000 \mathrm{MPa}$

Bayzoni (2016) mejabarkan keruntuhan pada kolom terjadi karena besarnya regangan pada baja tulangan yang tertarik pada penampang kolom, keruntuhan awal keruntuhan tersebut digolongkan menjadi 3 yaitu:

a. Keruntuhan Tarik; pada kondisi ini nilai regangan beton semakin kecil $\varepsilon_{\mathrm{cu}}<0,003$ dan nilai $\mathrm{c}<\mathrm{c}_{\mathrm{b}}$ sehingga gaya aksial nominal lebih kecil dari gaya aksial kondisi seimbang $\left(\mathrm{P}_{\mathrm{n}}<\mathrm{Pn}_{\mathrm{b}}\right)$

b. Keruntuhan Tekan; pada waktu runtuhnya kolom, beton akan mencapai kekuatan batasnya terlebih dahulu $\varepsilon_{\mathrm{cu}}=0,003$, tulangan tekan $\left(\mathrm{A}_{\mathrm{s}}{ }^{\prime}\right)$ telah mencapai leleh $\left(\mathrm{f}_{\mathrm{s}}{ }^{\prime}=\mathrm{f}_{\mathrm{y}}\right)$ sedangkan baja tulangan tarik belum leleh $\left(\varepsilon_{\mathrm{s}}<\varepsilon_{\mathrm{y}}\right.$ atau $\left.\mathrm{f}_{\mathrm{s}}<\mathrm{f}_{\mathrm{y}}\right)$

c. Keruntuhan Seimbang; pada kondisi ini regangan yang terjadi pada tulangan telah leleh $\left(\varepsilon_{\mathrm{s}}\right.$ $\left.=\varepsilon_{\mathrm{y}}\right)$ dan material beton juga mengalami kehancuran $\left(\varepsilon_{\mathrm{cu}}=0,003\right)$ secara bersama-sama.

\subsection{Diagram Interaksi}

Cara mudah untuk menentukan kekuatan nominal dan kekuatan rencana dari suatu kolom adalah dengan menggambarkan hubungan antara gaya aksial (P) dan momen (M) dalam sebuah kurva yang disebut diagram interaksi. Dengan diagram interaksi akan mempermudah untuk merencanakan atau mengevaluasi kekuatan suatu kolom apakah mampu menahan beban yang terjadi. Dimana sumbu $\mathrm{x}$ mewakili Momen (M) dan sumbu y mewakili gaya aksial (P). Diagram interaksi ini memberikan gambaran beban runtuh dan momen runtuh dari suatu penampang kolom, untuk setiap eksentrisitas dari nol sampai tak hingga (Setiawan, 2016). Diagram interaksi kolom dibuat sesuai dengan kebutuhan, terutama untuk melakukan pengecekan pada profil dengan konfigurasi tulangan yang telah ditentukan terbukti secara cepat dapat mengevaluasi apakah kombinasi gaya aksial-momen pada dua arah masih aman (Subrinato dkk., 2020). Kolom dikatakan kuat menahan beban dan momen yang terjadi ketika berada di dalam diagram ini. Kuat rencana pada penampang dihitung dengan mengalikan kuat nominal dan faktor reduksi kekuatan $(\phi)$ sebagaimana persamaan (1) dan (2) di atas.
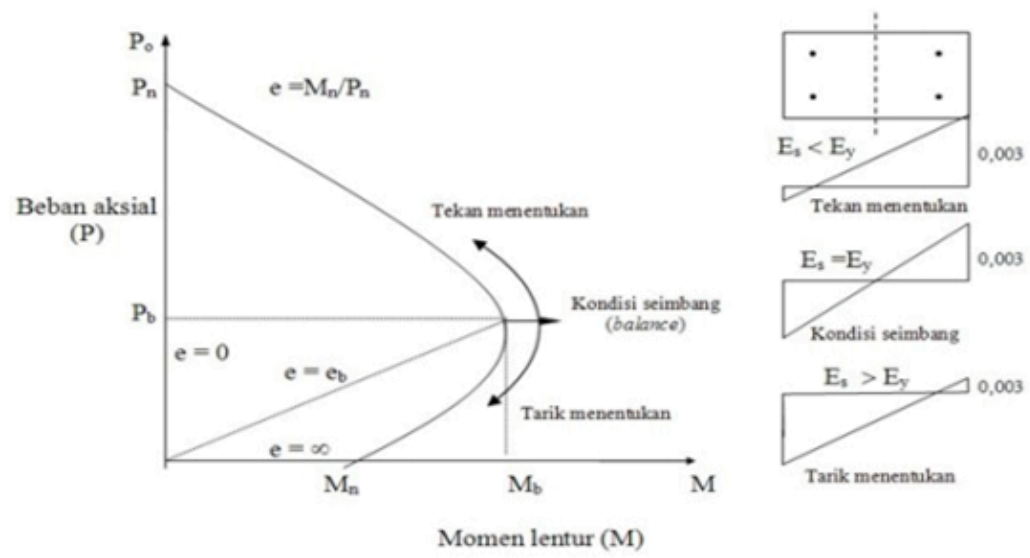

Gambar 2 Diagaram interaksi kolom P dan W (Wang, 1993)

(Sumber: Bayzoni, Irianti, \& Putri, 2016) 
Untuk menghitung hubungan antara gaya aksial dan lentur pada diagaram interaksi dapat menggunakan persamaan berikut ini,

$$
\begin{gathered}
P_{n}=C_{c}+C_{s}-T_{s} \\
M_{n}=C_{c} z_{c}+C_{s} z_{s}+T_{s} z_{t}
\end{gathered}
$$

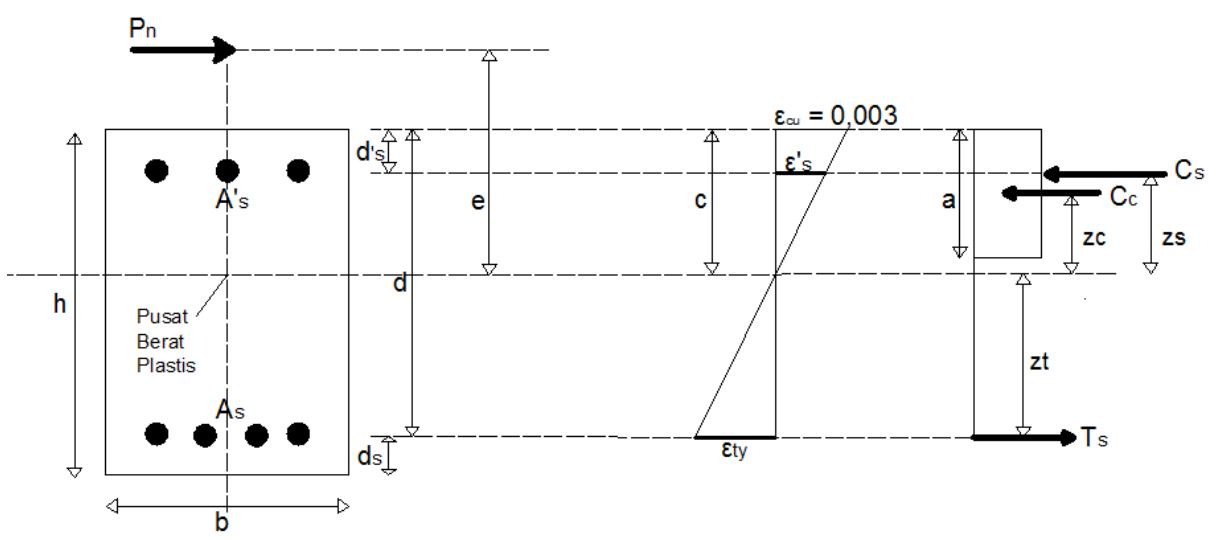

Gambar 3 Kondisi keruntuhan kolom

Apabila luas tulangan tekan $\left(\mathrm{A}^{\prime}{ }_{\mathrm{s}}\right)$ sama dengan luas tulangan tarik $\left(\mathrm{A}_{\mathrm{s}}\right)$, maka titik berat plastis akan berada di tengah tengah penampang sehingga rumus Mn menjadi:

$$
\begin{gathered}
M_{n}=C_{c}\left(\frac{h}{2}-\frac{a}{2}\right)+C_{s}\left(\frac{h}{2}-d_{s}^{\prime}\right)+T_{s}\left(d-\frac{h}{2}\right) \\
C_{c}=0,85 f^{\prime}{ }_{c} a b \\
C_{s}=A_{s}^{\prime}\left(f_{s}^{\prime}-0,85 f_{c}^{\prime}\right) \\
T_{s}=A_{s} f_{y} \\
a=\beta_{1} c
\end{gathered}
$$

dimana:

$$
\begin{array}{ll}
P_{n} & =\text { kekuatan aksial nominal } \\
M_{n} & =\text { momen nominal } \\
C_{c} & =\text { gaya tekan beton } \\
C_{s} & =\text { gaya tekan tulangan } \\
T_{s} & =\text { gaya tarik tualangan } \\
h & =\text { tinggi penampang kolom } \\
b & =\text { lebar penampang kolom } \\
a & =\text { jarak ekivalen blok tekan beton } \\
c & =\text { jarak dari serat tekan terjauh sampai ke sumbu netral } \\
d & =\text { tinggi efektif beton }
\end{array}
$$


$d_{s}^{\prime}, d_{s} \quad=$ jarak dari serat terluar ke as tulangan tekan/tarik

$f_{s}^{\prime}, f_{s} \quad=$ tegangan tekan/tarik baja tulangan

$f^{\prime}{ }_{c} \quad=$ mutu beton/kuat tekan beton

$f_{y} \quad=$ mutu baja tulangan

SNI 2013 dan SNI 2019 memberikan batasan nilai $\beta 1$ bervariasi $0,65-0,85$ tergantung mutu beton (f'c) sebagaimana Tabel 3 berikut ini

Tabel 3 Nilai $\beta 1$ untuk distribusi tegangan beton persegi ekuivalen

\begin{tabular}{cc}
\hline f'c (MPa) & $\boldsymbol{\beta 1}$ \\
\hline $17 \leq \mathrm{f}^{\prime} \mathrm{c} \leq 28$ & 0,85 \\
$27<\mathrm{f}^{\prime} \mathrm{c}<55$ & $0,85-\frac{0,05\left(\mathrm{f}_{\mathrm{c}}{ }_{\mathrm{c}}-28\right)}{7}$ \\
$\mathrm{f}^{\prime} \mathrm{c} \geq 55$ & 0,65 \\
\hline
\end{tabular}

Sumber: SNI 2019

Dimana nilai tegangan akibat tulangan tekan $\left(\mathrm{f}^{\prime}{ }_{\mathrm{s}}\right)$ dan tulangan tarik $\left(\mathrm{f}_{\mathrm{s}}\right)$ tidak boleh melebihi tegangan mutu baja tulangan $\left(\mathrm{f}_{\mathrm{y}}\right)$.

$$
\begin{gathered}
f^{\prime}{ }_{s}=600\left(\frac{c-d}{c}\right) \leq f_{y} \\
\varepsilon_{\mathrm{s}}^{\prime}=\frac{\mathrm{f}_{\mathrm{s}}^{\prime}}{\mathrm{E}_{\mathrm{s}}}=\frac{\mathrm{c}-\mathrm{d}^{\prime}}{\mathrm{c}}(0,003) \leq \varepsilon_{\mathrm{y}} \\
f_{s}=600\left(\frac{d-c}{c}\right) \leq f_{y} \\
\varepsilon_{s}=\frac{f_{s}}{E_{s}}=\frac{d-c}{d}(0,003) \leq \varepsilon_{y}
\end{gathered}
$$

Pada kondisi kolom mengalami keruntuhan seimbang, nilai $\varepsilon_{\mathrm{cu}}=\varepsilon_{\mathrm{ty}}$, sehingga didapatkan persamaan untuk menghitung variabel $\mathrm{c}$ dan a dalam kondisi seimbang sebagai berikut:

$$
\begin{gathered}
\frac{c_{b}}{d}=\frac{0,003}{0,003+\varepsilon_{t y}} \\
c_{b}=\frac{600}{600+f_{y}} d \\
\mathrm{a}_{\mathrm{b}}=\beta_{1} \mathrm{c}_{\mathrm{b}}=\frac{600}{600+\mathrm{f}_{\mathrm{y}}} \beta_{1} \mathrm{~d}
\end{gathered}
$$

\section{Hasil dan Pembahasan}

Langkah pertama dari penelitian ini adalah dengan menghitung junlah tulangang dimana rasio tulangan yang digunakan adalah sebesar $1 \%-8 \%$, namun pada studi kasus ini digunakan rasio 
tulangan $1 \%$ atau yang mendekati $1 \%$. Dengan menggunakan tulangan S16 -berdasarkan SNI 2052:2017 tentang Baja Tulangan Beton-, maka luas tulangan S16 adalah $201 \mathrm{~mm}^{2}$. Sehingga bila digunakan 10 buah tulangan S16 maka akan didapatkan rasio tulangan sebesar 1,005\% yang mendekati angka $1 \%$. Dengan mengasumsikan jumlah tulangan tarik dan tekan sama, maka sisi tekan berjumlah 5 buah tulangan S16 dan sisi tarik juga dipasang 5 buah tulangan S16.

Dengan menggunakan persamaan (10) hingga persamaan (20), maka akan didapatkan $P_{n}$ dan $M_{n}$ sebagaimana diagram interaksi yang ditunjukkan Gambar 4 berikut ini,

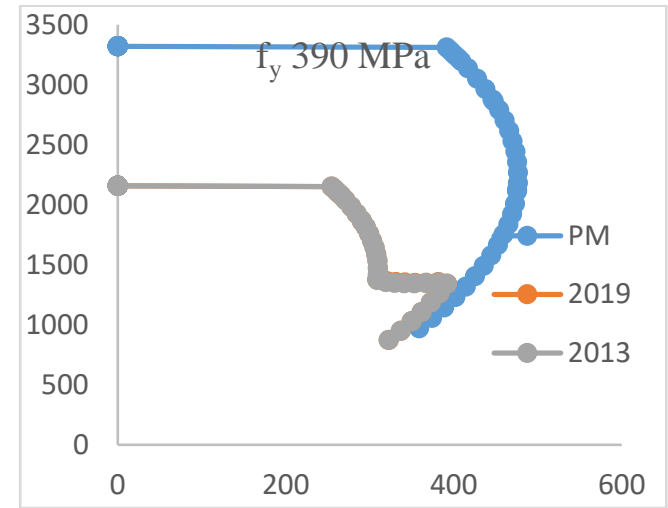

(a)

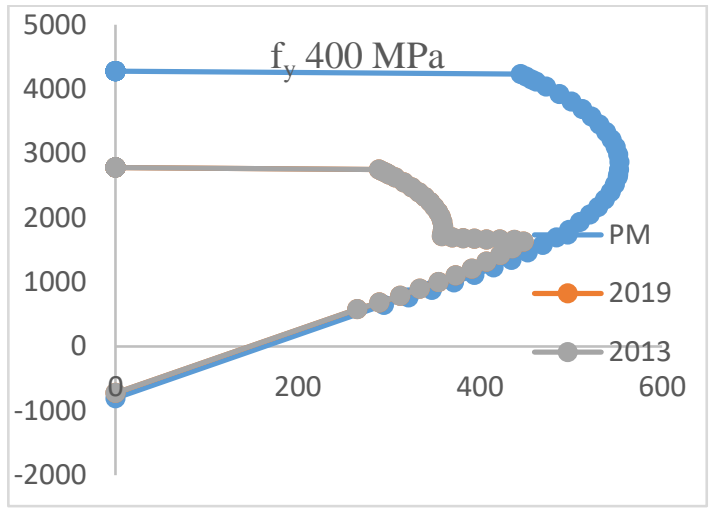

(b)

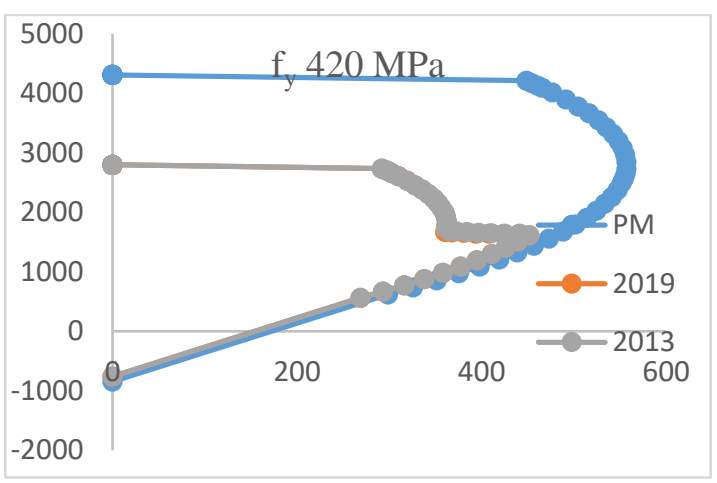

(c)

Gambar 4. Diagaram Interaksi dengan variasi $f_{y}$

Gambar 5 merupakan gambar diagaram interaksi dari kolom dengan ukuran 400x500 dengan mutu beton $\mathrm{f}_{\mathrm{c}}$ ' $20 \mathrm{MPa}$ dengan variasi $\mathrm{f}_{\mathrm{y}} 390 \mathrm{MPa}, 400 \mathrm{MPa}$ dan $420 \mathrm{MPa}$. Bila dilihat secara kasat mata, maka diagram interaksi ultimit (pada legenda dinotasikan sebagai 2013 dan 2019) di atas terlihat hampir tidak terlihat perbedaan yang signifikan. Untuk dapat besarnya perbedaan pada gambar diagram interaksi tersebut dapat dilakukan dengan membuat grafik/diagram perbandingan $\phi$ dengan variasi $\varepsilon_{\mathrm{t}}$ sebagaimana Gambar 5 .

Tabel 4 Gaya Maksimal dengan variasi $f_{y}$

\begin{tabular}{cccc}
\hline $\mathbf{P}, \mathbf{M}$ & $\mathbf{f}_{\mathbf{y}} \mathbf{3 9 0} \mathbf{M P a}$ & $\mathbf{f}_{\mathbf{y}} \mathbf{4 0 0} \mathbf{M P a}$ & $\mathbf{f}_{\mathbf{y}} \mathbf{4 2 0} \mathbf{M P a}$ \\
\hline $\mathrm{P}_{\text {nmax }}$ & 3319,968799 & 3336,053753 & 3368,223662 \\
$\mathrm{P}_{\mathrm{umax}}$ & 2157,979719 & 2168,434939 & 2189,34538 \\
$\mathrm{M}_{\mathrm{nmax}}$ & 476,5646342 & 478,5752535 & 482,5964921 \\
$\mathbf{M}_{\mathrm{umax}}$ & 392,1283995 & 393,9379569 & 397,5570716 \\
\hline
\end{tabular}


Selisih nilai $\phi$ antara SNI 2013 dan SNI 2019 dengan f 390 MPa terjadi pada nilai $\varepsilon_{\mathrm{t}}>\varepsilon_{\mathrm{ty}}$ hingga $\varepsilon_{\mathrm{t}}<0,005$. Dengan menganggap SNI 2019 sebagai nilai eksak, maka galat terbesar (absolut) adalah 0,627 pada $\varepsilon_{\mathrm{t}} 0,002$. Pada et 0,002 , nilai $\phi$ pada SNI 2013 sebesar 0,65 dan pada SNI 2019 sebesar 0,654098 . Galat berangsung-angsur mengecil seiring pertmabahan nilai $\varepsilon_{\mathrm{t}}$ hingga $\varepsilon_{\mathrm{t}}>=0,005$. Untuk nilai galat sebagaimana ditampilkan Gambar 6,

\section{$\mathrm{f}_{\mathrm{y}} 390 \mathrm{MPa}$}

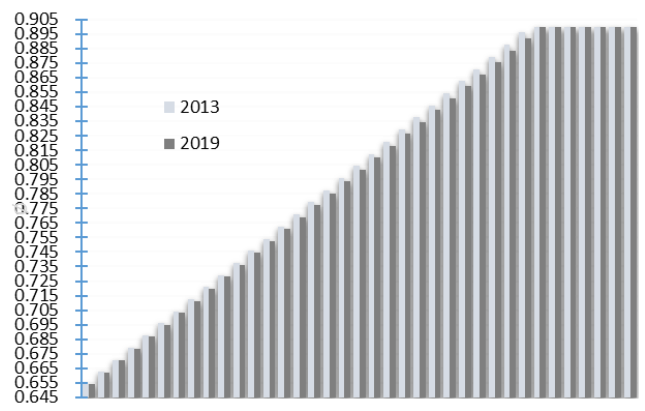

Gambar 5 Perbandingan \&t dengan fy 390 MPa

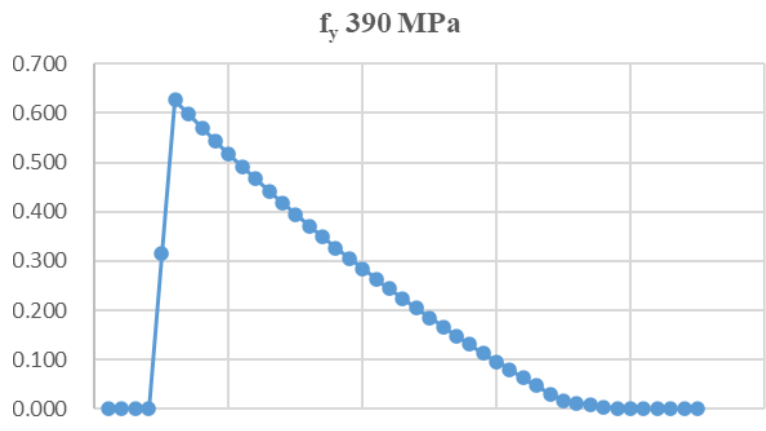

Gambar 6 Selisih $\phi$ dengan fy 390 MPa

Untuk kasus dimana $\mathrm{f}_{\mathrm{y}}$ sebesar 420, baik SNI 2013 maupun 2019 tidak terdapat perbedaan sama sekali. Namun dengan fy $420 \mathrm{MPa}$, perubahan nilai $\phi$ kembali terjadi pada daerah transisi dimana $\varepsilon_{\mathrm{t}}>\varepsilon_{\text {ty }}$ hingga $\varepsilon_{\mathrm{t}}<0,005$. Pada kasus $\mathrm{f}_{\mathrm{y}} 420 \mathrm{MPa}$, galat terbesar terjadi ketika nilai $\varepsilon_{\mathrm{t}}=\varepsilon_{\mathrm{ty}}=0,0021$ dan berngsur-angsur mengecil hingga niai $\phi 0,9$ pada $\varepsilon_{\mathrm{ty}} 0,005$.

\section{$f_{y} 400 \mathrm{MPa}$}

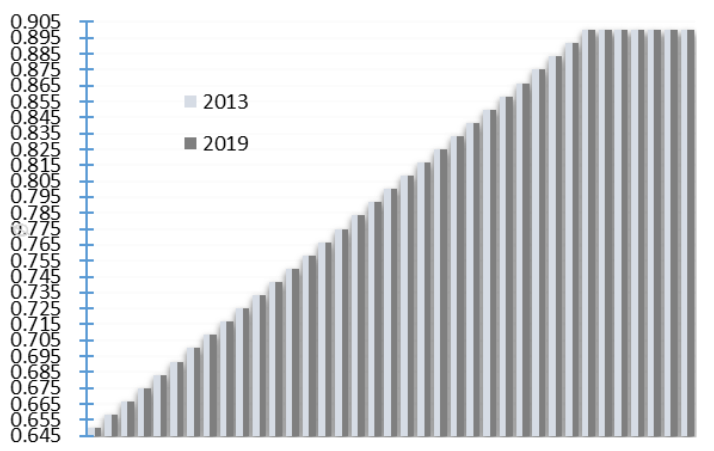

Gambar 7 Perbandingan \&t dengan fy $400 \mathrm{MPa}$ $\mathrm{f}_{\mathrm{y}} 420 \mathrm{MPa}$

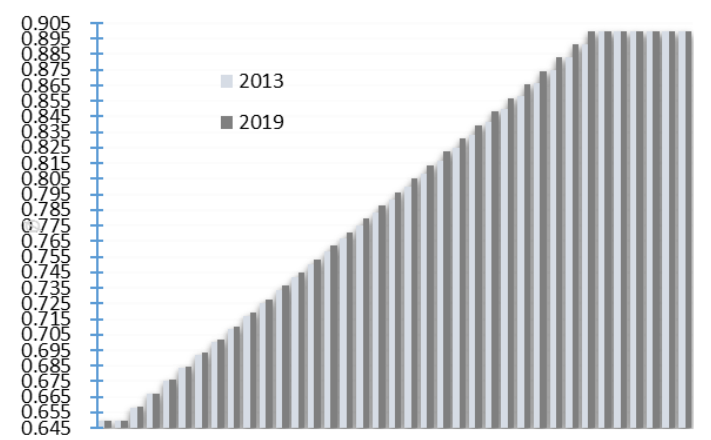

Gambar 8 Perbandingan \&t dengan f $420 \mathrm{MPa}$

$\mathrm{f}_{\mathrm{y}} 420 \mathrm{MPa}$

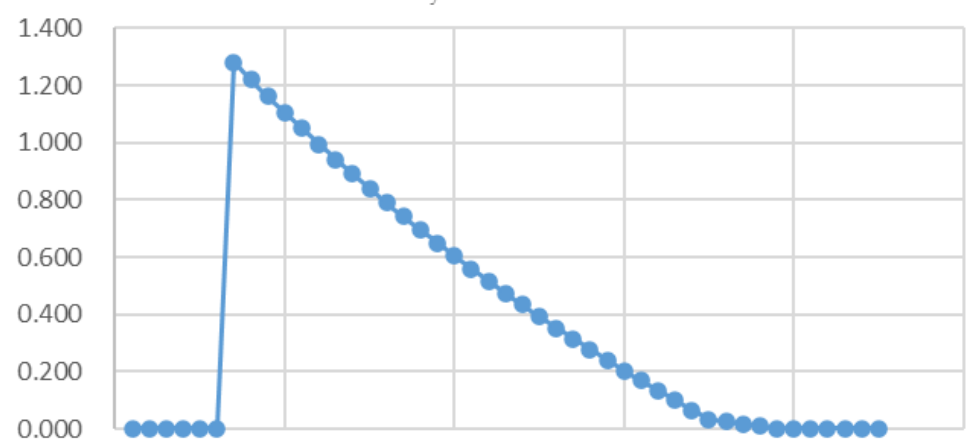

Gambar 9 Selisih $\phi$ dengan $\mathrm{f}_{\mathrm{y}} 420 \mathrm{MPa}$ 


\section{Kesimpulan}

Dari hasil analisis didapatkan bahwa dengan menggunakan rasio tulangan $1 \%$ maka akan didapatkan jumlah tulangan 10 buah apabila menggunakan tulangan S16. Penggunaan SNI 2013 dan SNI 2019 tidak memberikan pengaruh yang signifikan (walau terdapat perbedaan di daerah transisi) terhadap kekuatan ultimit maupun kekuatan nominal kolom dengan $\mathrm{f}_{\mathrm{y}}$ yang sama. Jadi dapat disimpulkan perencanaan yang masih menggunakan SNI 2013 terutama pada kolom tidak berpengaruh terhadap peraturan terbaru, SNI 2019.

\section{Daftar Pustaka}

Arfiadi, Y. (2016). Diagram Interaksi Perancangan Kolom Dengan Tulangan Pada Empat Sisi Berdasarkan SNI 2847:2013 dan ACI 318M-11. Jurnal Teknik Sipil, Vol: 13, No. 4, 268-290.

Asroni, A. (2010). Kolom, Fondasi dan Balok “T” Beton Bertulang. Yogyakarta: Graha Ilmu.

Badan Standarisasi Nasional. (2019). SNI 2847:2019 Persyaratan beton struktural untuk bangunan gedung dan penjelasan (ACI 318M-14 dan ACI 318RM-14, MOD). Jakarta: BSN.

Badan Standarisasi Nasional. (2013). SNI 2947:2013 Persyaratan beton struktural untuk bangunan gedung. Jakarta: BSN.

Bayzoni, Irianti, L. \& Putri, V.C. (2016). Evaluasi Perancangan Kolom Beton Bertulang dengan Metode Elemen Hingga. Jurnal Rekayasa, Vol. 20, No. 3.

Piscesa, B. (2006). Studi Komparatif Desain Penampang Elemen Beton Akibat Kombinasi Aksial dan Lentur Berdasarkan "Unified Design Provision" (ACI 318-2002) dan "Limit State Method” (SNI 2002). Skripi, ITS, Surabaya.

Purwono, R. \& Aji, P. (2013). Disain Kapasitas Struktur Daktail Tahan Gempa Kuat. Surabaya: ITS Press.

Sartika, Gunawan, I., \& Hisyam, E. S. (2017). Analisis Struktur Gedung Beton Bertulang Berdasarkan SNI 2847-2002 dan SNI 2847-2013 (Studi Kasus: Gedung C Rumah Sakit Ibu dan Anak "Rona" Pangkalpinang). Jurnal Fropil, Vol: 5, No. 1.

Setiawan, A. (2016). Perancangan Struktur Beton Bertulang (Berdasarkan SNI 2847:2013). Jakarta: Erlangga.

Subrianto, A., Puryanto, \& Firdausa, F. (2020). Evaluasi Kapasitas Penampang Kolom Beton Bertulang Menggunakan Diagram Interaksi. Pilar Jurnal Teknik Sipil, Vol. 15, No. 01. 